\title{
The Benefits of Implementation of an Instructional Strategy Model Based on the Brain's Natural Learning Systems in Inclusive Classrooms in Higher Education
}

\author{
https://doi.org/10.3991/ijet.v15i18.14753 \\ Rasmitadila $(\bowtie)$ \\ Universitas Djuanda, Jawa Barat, Indonesia \\ rasmitadila@unida.ac.id \\ Reza Rachmadtullah \\ Universitas PGRI Adibuana, Jawa Timur, Indonesia \\ Achmad Samsudin \\ Universitas Pendidikan Indonesia, Jawa Barat, Indonesia \\ Anna Riana Suryanti Tambunan \\ Universitas Negeri Medan, Sumatera Utara, Indonesia \\ Eri Ester Khairas \\ Politeknik Negeri Jakarta, Jakarta, Indonesia \\ Muhammad Nurtanto \\ Universitas Sultan Ageng Tirtayasa, Banten, Indonesia
}

\begin{abstract}
Instructional strategy in inclusive classrooms in higher education has not yet accommodated the needs and competencies. It must be achieved by students who have various characteristics, learning styles, and different obstacles. This research aims to explore the perceptions of student- teachers toward implementing an instructional strategy model based on the brain's natural learning system, particularly its benefits for all students in inclusive classrooms in higher education. Data were collected through an open observation and interviews on students to determine the benefits of an instructional strategy model based on the natural learning system of the brain. The data were analyzed using qualitative data analysis. The research produced four major themes consisting of self-regulation, peer relationship, self-direction, and self-concept. Instructional strategies based on the brain's natural learning system are very suitable to be implemented in inclusive classrooms in higher education. The findings have implications for teachers not only practices employing inclusive pedagogy in higher education institutions but also for teachers, especially in the design of instruction in inclusive classrooms for all levels of education.
\end{abstract}

Keywords-Brain's natural learning system, instructional strategy, inclusive classroom, higher education. 


\section{Introduction}

The implementation of instruction in inclusive classrooms in higher education does not only require the completeness of lecturers to complete all instructional materials at the end of the semester. The lecturers must also be able to create learning by the characteristics of students, learning styles, strengths, and weaknesses of each student [3]. It is intended that lecturers can accommodate all students' needs according to the learning goals and objectives of inclusive education set by the higher education [1][2]. The diverse characteristics of students in inclusive classrooms provide an overview of the challenges students will face as graduates who are ready to use their knowledge. They will meet all the pressures of work, the style of leading of superiors in a job, as well as individual differences that can come from friends or colleagues in one's position. No exception for special needs students (SNSs) who also play a role in a workplace or community. Lecturers must be able to understand the characteristics of SNSs well, strengths, learning styles, as well as weaknesses and obstacles they have, so that suitable learning methods in inclusive classrooms can be appropriately applied [3][4][5].

Friendly and active learning for SNSs in higher education is their right. It must be implemented in education to be able to ensure that all learners develop all of their potentials optimally in a comfortable and open environment. This thing is indicated by the involvement and participation of all parties in learning. This participation is not only intended for students when studying, but also learning belongs to educators or lecturers who are required to be able to create fun and active learning that refers to the uniqueness of all students [6][7][8].

However, the fact is that instruction in the classroom, uniquely inclusive classrooms where there are SNSs and regular students (RSs), still does not show learning that promotes justice, effectiveness, and comfort for all students. Preliminary studies conducted by researchers on inclusive classrooms in higher education show there are several issues related to the quality of learning in inclusive classrooms. Some of the problems that occur are:

1) Lecturers do not understand the characteristics of SNSs, so they are lacking in developing all academic and non-academic aspects that are very influential to the students' futures [9].

2) The learning approach or model used by lecturers is not friendly, not centered on students and tends to generalize all the characteristics of students [10].

3) Teaching materials and instructional media that are used are not friendly to learning or less responsive to the needs and abilities of all students.

4) Lack of attention and particular time for SNSs in understanding lecture material, so learning outcomes are not in line with learning targets.

5) The assessment process for SNSs is likened to RSs so that there is a tendency labeling negative for SNSs; Various problems that arise should be understood by all lecturers so that the needs and characteristics of students can achieve instructional objectives. 
The instructional strategy implemented by the lecturer is still centered on the lecturer as a central figure. Students are only listeners and learning objects. The lecturer does not position himself as a facilitator, or mediator in a series of instructional activities. Lecturers do not create involvement or active learning between RSs and SNSs. This condition makes learning monotonous, unfriendly to SNSs, and the quality of learning does not become better because it does not accommodate all the needs [11][12].

These conditions result in a learning atmosphere that is not friendly and does not provide justice for all students, especially SNSs. Instructional objectives are challenging to be achieved if these conditions persist in inclusive classrooms. The long-term goal of education for all students is to prepare them for when they have to work after graduation, and so far, this has yet to be realized and does not provide adequate competence when having to work in a company or other workplaces [13][14]. For this reason, lecturers must be able to create an instructional strategy model that can improve academic, social, and emotional aspects for SNSs in an inclusive class, by the characteristics of all students. The instructional strategy model that involves all class communities and can provide benefits in learning is an instructional strategy model that can be used by lecturers so that all the needs of all students are met [15][16][17]. One learning model that can be designed by lecturers is an instructional strategy model based on the brain's natural learning system. The brain's natural learning system is learning based on five learning systems: emotional learning, social learning, cognitive learning, physical, and reflective learning systems [19].

This research explores the benefits of implementing an instructional strategy model based on the brain's natural learning system that is carried out in inclusive classrooms in higher education.

\section{$2 \quad$ Literature Review}

\subsection{The brain's natural learning systems}

The brain's natural learning system is learning based on five learning systems: emotional learning, social learning, cognitive learning, physical, and reflective learning (see Figure 1). 


\section{The Brain's Natural Learning Systems}

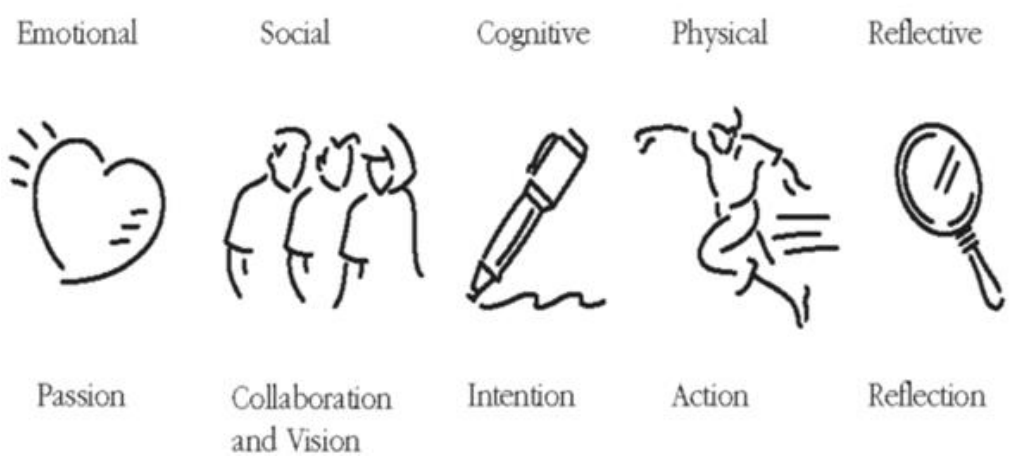

Fig. 1. The Brain's natural learning systems [19]

The emotional learning system is a learning system that places teachers as mentors, which creates a conducive classroom climate, making teacher-student and studentstudent relationships a warm relationship. Emotional systems provide opportunities for students to grow their talents and develop positive behavior towards the lessons learned [20]. The teacher functions to help foster a desire to learn and have a strong desire to be the best in the future by carrying out challenging learning that is relevant to the knowledge students have.

Social learning systems places students as part of groups with a focus on interaction with others by collaborating in a learning community and encourages the students to work together in making decisions and solving problems that can foster creativity students and teachers in learning. The teacher works with others to create environments that support individual and collaborative learning, encouraging positive social interaction, active engagement in learning, and self-motivation [21][22]. The cognitive learning system places the teacher in the role of facilitator. In contrast, students are placed as problem-solvers and decision-makers through providing learning space in a position that offers opportunities for students to explore knowledge, problemsolving, and decision making based on the instructional process that has been done. Vygotsky states that cognitive development is the result of social development through interaction with other people and the environment [23]. Learning designed in the zone of proximal development allows students to learn new knowledge within their abilities only with the help of teachers or peers. The teacher facilitates interaction through collaboration, mediation, and scaffolding, to help students build an understanding of skills that are appropriate to their development and abilities. The impact is students will be able to internalize learning, solve problems together as a team decision in a positive learning environment.

The physical learning system involves all class members in physical activity, psychomotor, and tactile on a topic being studied. Gardner's theory has in common with the physical learning system that is kinesthetic/bodily, which emphasizes the ability to use limbs and body movements to express ideas or thoughts [24]. Besides that, a skill uses hands to change or create something [25][26]. Physical activity in the classroom, 
such as performing certain movements besides increasing on social development, students can improve their performance in all school subjects [27], or correlated with academic results [28]. The reflective learning system places the teacher to understand students' learning styles, strengths, and weaknesses after going through the learning process. For students, this learning system provides a picture of what must be improved from a lesson and aids in measuring abilities and fostering strengths into talents that can be developed in the future [29]. The reflective development system describes all development systems that can show self-concept. Susan Harter's work has identified eight distinct aspects of the adolescent concept: scholastic competence, job competence, athletic competence, physical appearance, social acceptance, close friendships, romantic appeal, and conduct [30].

\subsection{Design of instructional strategies based on the brain's natural learning systems in inclusive classrooms in higher education}

The instructional strategy model based on the brain's natural learning system can ensure that all students are fully involved in learning. They gained the benefit from instructional activities carried out in inclusive classrooms [31][32]. Instruction in inclusive classrooms for SNSs in higher education is an opportunity to develop the quality of life in the future [33][34]. Learning must be directed to achieve competencies that can support increased benefits for SNSs when they have to employment in a particular agency or company. In learning, SNSs must be able to position themselves in the community environment, which is the most significant part of the consequences of education taken. Learning must be able to create confidence, high motivation to achieve educational goals, encourage communication, or interacting well with others, according to the needs and characteristics of SNSs [35][36]. Learning must be directed so that SNSs can collaborate in teamwork that promotes differences, respect for opinions, and mutual respect for each decision in a work team between student groups. Direct practices in learning that reflect appreciation and provide the best abilities of all students, including SNSs, will produce maximum competence for SNSs in readiness to enter the world of work and society. Figure 2 is the design of instructional strategies based on the brain's natural learning systems in inclusive classrooms in higher education: 


\begin{tabular}{|l|l|l|l|l|}
\hline $\begin{array}{l}\text { Em otional Leam- } \\
\text { ing System }\end{array}$ & $\begin{array}{l}\text { Class conditioning } \\
\text { Matching the relevance } \\
\text { and benefits of learning }\end{array}$
\end{tabular}

Fig. 2. The main design of the Instructional strategy model based on the brain's natural learning systems (source from [19] developed by Rasmitadila)

The linkage of the five natural brain learning systems for all students will align instructional objectives according to students' needs. It also offers the gaining of knowledge and experience through collaboration, fostering action and active involvement of all students, and understanding the strengths, weaknesses, and progress that have been achieved.

\section{Methodology}

This research uses a qualitative research approach to understand opinions and observations of learning outcomes for students about the implementation of an instructional strategy model based on the brain's natural learning system in inclusive classrooms in higher education. Qualitative research is used to explore people's opinions or thoughts in understanding research questions in-depth on the topic being studied [37].

\subsection{Participants}

Participants involved in this study were from an inclusive classroom at one of the Private Universities in West Java, Indonesia. The inclusive classroom was a class on inclusive education courses in elementary schools (PISD). The number of students in the inclusive classroom chosen was twenty-four students, with two SNSs and as many as twenty-two students that were RSs. The researcher chose this class because there were some SNSs. SNSs consist of one person with the category of slow learning, and one with a limb disorder. Characteristics of students who are slow learners have low 
learning motivation, and low academic motivation and focus and attention in learning involvement is also low. The students with limb disorders have limitations in moving the right hand, so they have limitations in writing activities and activities related to their hands. Class selection with PISD course considers that with SNSs, researchers will be able to analyze the strengths and weaknesses of the instructional strategies. Beside used so that improvements in the framework of perfecting the instructional strategy based on the brain's natural learning system can be done through the opinions of RSs and SNSs. In addition to classroom observation, another critical consideration is that through this instructional strategy, it is hoped that SNSs can improve their academic, social and emotional abilities so that they can be used in the future. Lecturers involved in learning were lecturers who have competence in teaching in inclusive classrooms and had taught for nine years. In the implementation of learning using instructional strategies based on the brain's natural learning system, lecturers who teach do not provide training in advance. Still, the lecturer introduces and explains the strategy designed to all students so that they know the stages of the instructional strategy that will be implemented in the classroom.

\subsection{Data collection}

Information on research data was generated from several data sources through observations and interviews. Observations were made on the instructional process using the instructional strategy model based on the brain's natural learning system from the beginning of instruction to the end of instruction. Observations were made to document the instructional process between lecturers and students, as well as students and students. The observation guide instrument related to instruction using an instructional strategy model based on the brain's natural learning system. The observation was conducted by recording all instructional activities using a recording device (audiovisual or audio). The recording was done from the beginning to the end of instruction, which had been designed by the lecturer. Results of observations, in addition to the results of the checklist produced, consisted of brief observations and observations made in detail that produced field notes in the form of all activities, lecturers 'and students' remarks that occurred during instruction.

Interviews were conducted face-to-face between researchers and informants. The informants in this study were students who were carrying out learning using the brain's natural instructional strategy model. The interview topic was about student opinion about the benefits of implementing the brain's natural learning systems of the instructional strategy model. The interview instrument was in the form of an interview guide related to the instructional process used as an instructional strategy model based on the brain's natural learning system, which consisted of 10 main questions. It can be developed into other problems with an open interview system for students.

Primary research data were in the form of video and audio recordings, especially the instructional process based on the brain's natural instructional strategy model. All instructional activities were recorded using a video camera and voice recorder. One camera was always in front of the class, while the other camera followed the lecturer and student activities when interacting. There were 14 observation activities with 1.5- 
2 learning hours of learning each. Researchers only chose five observations as data to be analyzed based on the fact that the natural instructional strategy model of the brain had been implemented well. The results of this recording were transcripts to be used as a more detailed data analysis. Transcript results and interview results were analyzed using qualitative data analysis to obtain further results.

\subsection{Setting and materials}

The university where the study was conducted is a private university that openly accepts all students' characteristics, both RSs and SNSs. As a Tauhid (monotheism)based university that is based on faith by providing justice for every human being, especially in education, it is very suitable if this university is considered one of the best universities in West Java. Classes are set as best as possible, not only physically like chairs, desks, or other learning tools, but also possesses an academic atmosphere that provides comfort and conduciveness for all students to study. Learning is carried out in the classroom and outside the classroom, including observations, theory, and learning practice. During the study, instructional materials took the form of inclusive education, the history of inclusive education, the definition of students with special needs, identification and assessment, and curriculum and inclusive classroom learning into consideration. The instructional process was carried out by a lecturer who had taught for five years and had competence in teaching courses in inclusive education. In addition to regular learning needs, for research needs, lecturers make models of instructional strategies based on the brain's natural learning system. Table 2 below is an example of an instructional strategy model based on the brain's natural learning systems:

Table 1. An example design of instructional strategy model based on the brain's natural learning systems in one subject

\begin{tabular}{|c|l|l|l|l|l|l|l|l|}
\hline No & $\begin{array}{l}\text { Topic of } \\
\text { instruction }\end{array}$ & $\begin{array}{l}\text { The } \\
\text { brain's } \\
\text { natural } \\
\text { learning } \\
\text { systems } \\
\text { process }\end{array}$ & $\begin{array}{c}\text { Instruction } \\
\text { sequence }\end{array}$ & Methods & Media & $\begin{array}{l}\text { Time } \\
\text { Instruction } \\
\text { materials } \\
\text { alloca- } \\
\text { tion (in } \\
\text { a } \\
\text { mi- } \\
\text { nute) }\end{array}$ \\
\hline ment \\
\hline 1
\end{tabular}




\begin{tabular}{|c|c|c|c|c|c|c|c|c|}
\hline No & $\begin{array}{l}\text { Topic of } \\
\text { instruction }\end{array}$ & $\begin{array}{l}\text { The } \\
\text { brain's } \\
\text { natural } \\
\text { learning } \\
\text { systems } \\
\text { process }\end{array}$ & $\begin{array}{l}\text { Instruction } \\
\text { sequence }\end{array}$ & Methods & Media & $\begin{array}{l}\text { Instruction } \\
\text { materials }\end{array}$ & $\begin{array}{l}\text { Assess- } \\
\text { ment }\end{array}$ & $\begin{array}{l}\text { Time } \\
\text { alloca- } \\
\text { tion (in } \\
\text { a } \\
\text { mi- } \\
\text { nute) }\end{array}$ \\
\hline & & & $\begin{array}{l}\text {-The lecturer } \\
\text { asks the stu- } \\
\text { dent's opinion } \\
\text { about the film } \\
\text {-The lecturer } \\
\text { explains the } \\
\text { relevance of the } \\
\text { video to the } \\
\text { topic } \\
\text {-The lecturer } \\
\text { explains the } \\
\text { purpose and } \\
\text { benefits of } \\
\text { learning. }\end{array}$ & & & & & \\
\hline \multicolumn{9}{|c|}{ Main instructional activities } \\
\hline 2 & & $\begin{array}{l}\text { Social } \\
\text { learning } \\
\text { system }\end{array}$ & $\begin{array}{l}\text {-The lecturer } \\
\text { divides eight } \\
\text { groups to start } \\
\text { learning } \\
\text {-The lecturer } \\
\text { provides several } \\
\text { photos and } \\
\text { initial types of } \\
\text { children with } \\
\text { special needs in } \\
\text { each group } \\
\text {-The lecturer } \\
\text { asks each group } \\
\text { to look for } \\
\text { characteristics } \\
\text { of students with } \\
\text { special needs } \\
\text {-The lecturer } \\
\text { asks each group } \\
\text { member to share } \\
\text { their opinions } \\
\text { and explana- } \\
\text { tions about the } \\
\text { given assign- } \\
\text { ment. }\end{array}$ & \begin{tabular}{|l|} 
\\
-Discussion \\
-Q \& A \\
\end{tabular} & $\begin{array}{l}\text { - } \\
\text { White- } \\
\text { board } \\
\text {-Internet }\end{array}$ & $\begin{array}{l}\text {-Textbook } \\
\text {-Journal }\end{array}$ & -Rubric & $20^{\prime}$ \\
\hline 3 & & $\begin{array}{l}\text { Physical } \\
\text { learning } \\
\text { system }\end{array}$ & $\begin{array}{l}\text {-The lecturer } \\
\text { explains to each } \\
\text { group about } \\
\text { Braille (Blind) } \\
\text { and CIBI (deaf) } \\
\text { finger props } \\
\text {-The lecturer } \\
\text { divided four } \\
\text { groups to prac- } \\
\text { tice using } \\
\text { Braille, and four } \\
\text { groups practiced }\end{array}$ & $\begin{array}{l}\text {-Discussion } \\
\text {-Practice }\end{array}$ & $\begin{array}{l}\text {-Internet } \\
\text {-Cartoon }\end{array}$ & -Textbooks & -Rubric & $15^{\prime}$ \\
\hline
\end{tabular}




\begin{tabular}{|c|c|c|c|c|c|c|c|c|}
\hline No & $\begin{array}{l}\text { Topic of } \\
\text { instruction }\end{array}$ & $\begin{array}{l}\text { The } \\
\text { brain's } \\
\text { natural } \\
\text { learning } \\
\text { systems } \\
\text { process }\end{array}$ & $\begin{array}{l}\text { Instruction } \\
\text { sequence }\end{array}$ & Methods & Media & $\begin{array}{l}\text { Instruction } \\
\text { materials }\end{array}$ & $\begin{array}{l}\text { Assess- } \\
\text { ment }\end{array}$ & $\begin{array}{l}\text { Time } \\
\text { alloca- } \\
\text { tion (in } \\
\text { a } \\
\text { mi- } \\
\text { nute) }\end{array}$ \\
\hline & & & $\begin{array}{l}\text { the CIBI finger } \\
\text { movements }\end{array}$ & & & & & \\
\hline 4 & & $\begin{array}{l}\text { Cognitive } \\
\text { learning } \\
\text { system }\end{array}$ & $\begin{array}{l}\text {-The teacher } \\
\text { gives a roll of } \\
\text { paper to each } \\
\text { group that } \\
\text { contains the } \\
\text { topics that have } \\
\text { been discussed } \\
\text {-The lecturer } \\
\text { asks each group } \\
\text { to present their } \\
\text { assignments on } \\
\text { the role of paper } \\
\text {-The lecturer } \\
\text { allows other } \\
\text { groups to be } \\
\text { able to ask the } \\
\text { group who is } \\
\text { performing their } \\
\text { task }\end{array}$ & \begin{tabular}{|l} 
\\
-Presentation \\
-Q n A \\
\\
\end{tabular} & $\begin{array}{l}\text { - } \\
\text { White- } \\
\text { board } \\
\text {-Internet }\end{array}$ & -Textbook & -Rubric & 20 ' \\
\hline \multicolumn{9}{|c|}{ Closing instructional activities } \\
\hline 5 & & $\begin{array}{l}\text { Reflective } \\
\text { learning } \\
\text { system }\end{array}$ & $\begin{array}{l}\text {-The lecturer } \\
\text { asks all groups } \\
\text { about what they } \\
\text { have learned } \\
\text {-The lecturer } \\
\text { explains the } \\
\text { weaknesses and } \\
\text { strengths of } \\
\text { learning for } \\
\text { each group } \\
\text {-The lecturer } \\
\text { reinforces each } \\
\text { group against } \\
\text { the weaknesses } \\
\text { that arise } \\
\text {-The lecturer } \\
\text { reinforces } \\
\text { learning at the } \\
\text { next meeting to } \\
\text { be better }\end{array}$ & \begin{tabular}{|l} 
\\
\\
-Lecturer \\
-Q \& A \\
-Mindmap
\end{tabular} & $\begin{array}{l}\text { White- } \\
\text { board }\end{array}$ & - & - & $20^{\prime}$ \\
\hline & \multicolumn{8}{|c|}{$\begin{array}{l}\text { Lecturer comments on learning } \\
\text {-The power of learning: } \\
\text { Today, learning is very challenging and fun. Each group jointly conducts exercises and discussions } \\
\text { enthusiastically and actively. Especially in practicing Braille and CIBI letters. For them, this is the } \\
\text { first experience in learning reading techniques for students with special needs. } \\
\text {-Learning Weaknesses: } \\
\text { Some weaknesses in learning are still visible, among others: the dominance of some group leaders } \\
\text { who tend to be selfish in making decisions. Some students with special needs are still not active in } \\
\text { discussions, so they must be reminded to be active. They always tend to be shy in giving opinions in } \\
\text { groups. }\end{array}$} \\
\hline
\end{tabular}




\begin{tabular}{|c|c|c|c|c|c|c|c|c|}
\hline No & $\mid \begin{array}{l}\text { Topic of } \\
\text { instruction }\end{array}$ & $\begin{array}{l}\text { The } \\
\text { brain's } \\
\text { natural } \\
\text { learning } \\
\text { systems } \\
\text { process }\end{array}$ & $\begin{array}{l}\text { Instruction } \\
\text { sequence }\end{array}$ & Methods & Media & $\begin{array}{l}\text { Instruction } \\
\text { materials }\end{array}$ & $\begin{array}{l}\text { Assess- } \\
\text { ment }\end{array}$ & \begin{tabular}{|l} 
Time \\
alloca- \\
tion (in \\
a \\
mi- \\
nute) \\
\end{tabular} \\
\hline & \multicolumn{8}{|c|}{$\begin{array}{l}\text {-Follow-up: } \\
\text { For the next meeting, lecturers should be able to use more varied learning methods and encourage all } \\
\text { students to play an active role in learning. Methods like training with friends, role-playing are good } \\
\text { examples of topics for the next meeting. }\end{array}$} \\
\hline
\end{tabular}

\subsection{Data analysis}

Before the data were analyzed further, the first step was to make transcripts from various data sources (video / audio) from observations and interviews. In the interview results, the researcher analyzed the interview notes that determined the phrases associated with the instructional process related to the five brain's learning systems in the natural instructional strategy model. The results of the observations were put in the form of field notes. Then the data was used to produce code from the field notes by research questions. The research code was recorded to identify the instructional process from the beginning to the end of instruction, where the brain's natural instructional strategy model was implemented.

Researchers applied a qualitative analysis [38] and modified by [39][40] with three steps of analysis, namely:

- Thematic analysis of all participants, observing instructional activities from the beginning to the end of instruction both between teacher and student, and students and students, making field notes, coding, and interviewing students.

- Within-participants thematic analysis, identifying common themes from each learning activity.

- Cross participant analysis, identifying common themes among participants.

The final step in data analysis produced a cultural theme as a profile of implementing the brain's natural instructional strategy model in inclusive classrooms in higher education.

Table 2. Qualitative Data Analysis

\begin{tabular}{|l|l|l|}
\hline \multicolumn{1}{|c|}{ Included Term } & \multicolumn{1}{c|}{ Semantic Relation } & \multicolumn{1}{c|}{ Cover Term } \\
\hline $\begin{array}{l}\text { - Increase the desire to learn (motivation) } \\
\text { - Desire to achieve goals according to their } \\
\text { talents }\end{array}$ & Is part of & Self-regulation \\
\hline $\begin{array}{l}\text {-Build collaboration in learning } \\
\text {-Enhance instructional interactions }\end{array}$ & Is part of & Peer relationship \\
\hline $\begin{array}{l}\text {-Explore the new knowledge } \\
\text { - Enhance learning experiences }\end{array}$ & Is part of & Self-direction \\
\hline -Know the strengths, abilities, and weaknesses & Is part of & Self- concept \\
\hline
\end{tabular}




\section{$4 \quad$ Result and Discussion}

Based on data analysis performed, this study produced a profile of the benefits of an instructional strategy model based on the brain's natural learning systems in inclusive classrooms in higher education.

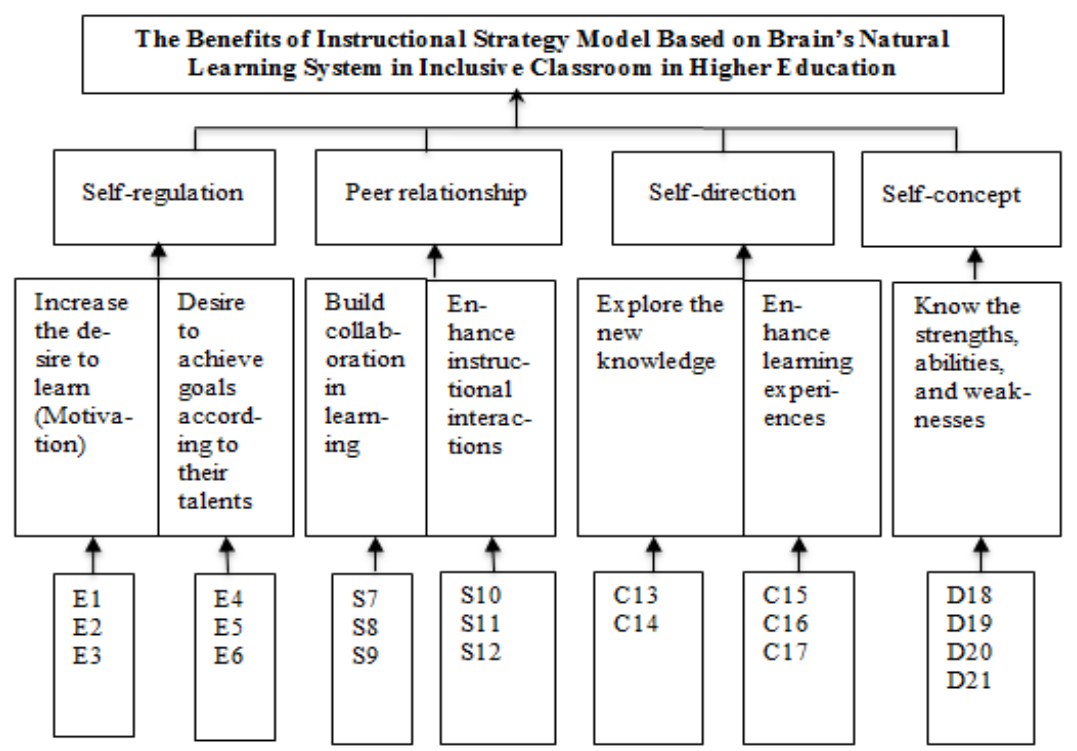

Fig. 3. The Benefits of an instructional strategy model based on the brain's natural learning system in an inclusive classroom in higher education

Note:

- E1: The lecturer does icebreaking

- E2: The lecturer invites students to sing

- E3: The teacher makes a simple game

- E4: The lecturer plays the film

- E5: The lecturer explains the relevance of the lesson

- E6: The lecturer explains the aims and benefits of the lesson

- S7: The lecturer asks students to study according to their group

- S8: The lecturer gives the task of discussing with fellow group members about the film that has been screened

- S9: The lecturer gives a roll of paper to each group member that contains a theme for which an explanation should be found

- S10: The lecturer asks each group member to present their findings on the theme among group members

- S11: Lecturers provide opportunities for students with special needs to study together with regular students 
- S12: The lecturer asks each group to present the discussion's results in front of the class by the theme

- C13: Lecturers provide opportunities for group members to use the learning resources (journal, Internet, textbooks) that have been provided to find topics.

- C14: Lecturers provide the opportunity to use the Internet to find the right journal to recover data by the theme

- C15: The lecturer allows each group member to give each other input, as well as criticism of each theme explained by other group members.

- C16: The lecturer allows other group members to assess the presentation process related to the contents of the theme explained in front of the class

- C17: The lecturer allows each group to conclude each theme discussed in front of the class

- D18: The lecturer gives reinforcement of the material being discussed

- D19: The lecturer explains the challenges and obstacles to the theme being discussed

- D20: The lecturer evaluates the strengths and weaknesses of each group

- D21: The lecturer summarizes the results of the discussion

Based on the profile in Figure 3, four themes are the benefits of instructional strategies based on the brain's natural learning system, which can be explained in detail in the discussion of this study. The four themes are self-regulation, peer relationship, self- direction, and self-concept.

\subsection{Benefit 1: Self-regulation}

The emotional learning system aims at implementing learning in the initial activities that can arouse student learning interest, as well as foster motivation to learn so that it will facilitate students to achieve learning goals that have been set. The benefits felt by all students in learning are expected to be a strong foundation if they are faced with work in the future. As graduates who have organized self-regulation, they can plan, organize, measure, and instruct themselves in achieving performance [41]. Another benefit is that students are expected to be able to increase self-motivation by organizing themselves, in the context of channeling their talents and interests. This opinion is as expressed by students:

"For me, at the beginning of learning, it gives an idea of how I will have to work

later. I certainly need a high motivation, and will only carry out work by my interests, so that what I want can be achieved."

Self-regulation needed at the beginning of instruction but measuring the success of instruction can be done at each stage until the end of learning. The achievement of instructional objectives is the endpoint of self-regulation and will be re-evaluated repeatedly, both successes and failures that are not by the learning objectives. The benefits of self-regulation for students can make the classroom a world of work that will involve elements of emotion, thought, motivation [40], and engage the talents and interests that are preferred to achieve the goals set, or learning outcome [42]. For the 
future, special self-regulation students can help prepare them to prepare for work and independence in order to achieve success [43].

\subsection{Benefit 2: Peer relationship}

The social learning system aims to provide opportunities for all students, including SNS, to work together and interact in completing academic assignments. The key to peer relationships is that each friend has the same level of acceptance [44][45]. In inclusive classes, conditions of peer acceptance often become a problem, due to the shortcomings that some students have, including difficulty in communicating and tend to shut down or even anti-social from their friends. The teacher's role as a unifier of all student characteristics is significant so that all students can work together in a solid team. Peer relationships in the inclusive classroom, particularly to SNSs provide opportunities for all students to develop communication skills and networks, friendships [46][47], and problem-solving practices together. This opinion was conveyed by one of the SNSs:

"One of my difficulties in working with peers is because I shut myself down to interact. But now the lecturer allows me to have the same rights as a team in expressing opinions."

The benefits of positive peer relationships as an implementation of the social learning system in learning were to place all students, including SNSs, as part of the same group. Peer relationships will feature academic skills, prosocial behavior, and leadership qualities [48][49].

\subsection{Benefit 3: Self-direction}

Cognitive learning systems and physical learning systems aim to enable students to explore knowledge and make decisions about the problem or topic being studied [50]. The benefits of these two learning systems, form a self-direction of students so that they can use all resources and access to all learning resources, to be processed and used by the learning needs and learning objectives to be achieved. According to their characteristics and obstacles, self-direction for SNS provides benefits to manage to learn with RSs. SNS can put out its best ability to gain new knowledge and learning experiences both independently and in RS's assistance, which can be done continuously in learning activities. Self-direction refers to the learner's ability to evaluate and make decisions within a particular domain of knowledge and closely associated with informal learning and life-long learning [19][51]. The following is the opinion of the RS about self-direction:

"We are allowed by lecturers to determine what methods are appropriate in discussing a topic. Although in general, the lecturer asked us to discuss in small groups".

As a facilitator, the teacher provides and opens access to learning resources so that all students can use them. The use of smart mobile devices strongly supports the search for data needed by students in processing information [52-53], learning experiences, improves the cognitive and critical skills of learners [54-56]. The benefits of 
self-direction for students can be trained so that later in the work environment can determine the planning, implementation, and performance evaluation that has been determined for its purpose [57].

\subsection{Benefit 4: Self-concept}

The reflective learning system aims to make all students, including SNS, know their weaknesses, strengths, and abilities both in learning and long-term goals when choosing their jobs. The benefits of a reflective system are the formation of students' self-concepts, obtained through self-regulation (emotional) and self-direction (cognitive) in positive relationships (social) or interaction with peers and teachers in learning activities [58][59-61]. Self-concept becomes a capital for students to hone strengths, correct weaknesses, improve abilities, and maintain positive values that will be used in every learning and work activity [21][62]. Students can feel what should be improved in learning so far; they rarely get feedback after implementing learning. For SNS, self-concept needs to be sharpened so that all the weaknesses that can be used as a basis for strengthening values and strengths [63]. The statement related to selfconcept was explained by one of the SNS:

"During this time, I did not know what my best ability was when studying, but now openly, the teacher gave that I was able to do work according to my characteristics."

Reflective learning systems have shaped students' self-concepts. The impact of self-concept was on the beliefs and values, attitudes, and expectations of students, as well as social relationships that occur in instructional activities [64-66].

The five natural learning systems of the brain that are practiced in instructional activities have benefited all students. The connectedness of the five learning systems also forms interrelated and influential benefits. Self-regulation is the concept of managing emotions, thoughts, motivation, and interest in setting learning goals. A peer relationship is a condition that every student is accepted as the same individual in status to be able to achieve academic skills. Self-direction shapes students to be able to process all learning resources, plan, implement, and assess learning independently and others. Self-concept provides an overview of students' strengths, weaknesses, abilities, and values.

\section{Conclusion}

Implementation of an instructional strategy model based on the brain's natural learning system in inclusive classrooms in higher education provides four benefits: self-regulation, peer relationship, self-direction, and self-concept. The four benefits felt by students are interrelated and affect the success of learning in inclusive classrooms. The benefits of self-regulation will affect student acceptance as part of groups with the same rights and status in learning. It will also have an impact on the management of student learning in planning, implementing, and evaluating learning. Even 
in the end, students can know the strengths, weaknesses, values, and abilities possessed in achieving learning objectives.

Instructional strategies based on the brain's natural learning system are very suitable for inclusive classrooms in higher education, as students who are expected to learn independently according to the development of the current learning revolution. The long-term benefits for students in instruction can be used when they enter the workforce. This instructional strategy is expected to be practiced by teachers, academics, as well as a reference for other researchers always to be able to renew instructional strategies that are in line with educational development, especially in the design of instruction in inclusive classrooms for all levels of education.

\section{Acknowledgement}

This work was supported by the Ministry of Research, Technology, and Higher Education of the Republic of Indonesia through Grant the Assistance with Special Learning Innovations in Higher Education, 2019.

\section{$7 \quad$ References}

[1] O. Ungar, A. Margaliot, E. Grobgeld, and B. Leshem, "Faculty Use of the Active Learning Classroom: Barriers and Facilitators," J. Inf. Technol. Educ. Res., vol. 17, no. 1, pp. 485504, 2018.

[2] S. K. Raley, K. A. Shogren, and A. McDonald, "How to Implement the Self-Determined Learning Model of Instruction in Inclusive General Education Classrooms," Teach. Except. Child., vol. 51, no. 1, pp. 62-71, 2018. https://doi.org/10.1177/0040059918790236

[3] J. Pierce and V. Buyssee, "Effective coaching: improving teacher practice and outcomes for all learners," Natl. Cent. Syst. Improv. Brief Nov, 2014.

[4] A.-A. Darrow and M. Adamek, "Instructional Strategies for the Inclusive Music Classroom," Gen. Music Today, vol. 31, no. 3, pp. 61-65, 2018. https://doi.org/10.1177/1 $\underline{048371318756625}$

[5] I. M. Pit-ten Cate, M. Markova, M. Krischler, and S. Krolak-Schwerdt, "Promoting Inclusive Education: The Role of Teachers' Competence and Attitudes.," Insights Learn. Disabil., vol. 15, no. 1, pp. 49-63, 2018.

[6] K. L. Rush-Idigo, "Co-Teaching and Collaboration: The Effects of Planning and Implementing Differentiated-Instruction in an Inclusive Classroom to Improve Student Achievement.," ProQuest LLC, 2017.

[7] K. M. Fisher, "An Assessment of Student Learning and Instructional Methods in a Golf Skills Physical Education Course at a Public University," Phys. Educ., vol. 76, no. 2, pp. 410-426, 2019. https://doi.org/10.18666/tpe-2019-v76-i2-8715

[8] R. Tham and L. Tham, "The effectiveness of game-based learning as an instructional strategy to engage students in higher education in Singapore," Int. J. E-Learn., vol. 13, no. 4, pp. 483-496, 2014.

[9] A. Ayebo and C. Assuah, "Exploring Teachers' Knowledge of Classroom Management and Control.," Malays. J. Learn. Instr., vol. 14, no. 1, pp. 169-185, 2017. https://doi.org/ $\underline{10.32890 / \mathrm{mjli2} 2017.14 .1 .7}$ 
[10] M. Azeem and L. Mataruna, "Identifying factor measuring collective leadership at academic workplaces,” Int. J. Educ. Manag., 2019. https://doi.org/10.1108/ijem-04-2018-0131

[11] S. A. Ngubane-Mokiwa and S. B. Khoza, "Lecturers' experiences of teaching STEM to students with disabilities," 2016.

[12] H. Friziellie, J. A. Schmidt, and J. Spiller, Yes We Can!: General and Special Educators Collaborating in a Professional Learning Community. Solution Tree Press, 2016.

[13] J. M. Kauffman, M. Felder, B. Ahrbeck, J. Badar, and K. Schneiders, "Inclusion of all students in general education? International appeal for a more temperate approach to inclusion,” J. Int. Spec. Needs Educ., vol. 21, no. 2, pp. 1-10, 2018. https://doi.org/10.9782/17$\underline{00009}$

[14] Y. Li, K. M. Sheldon, J. N. Rouder, D. A. Bergin, and D. C. Geary, "Long-Term Prospects and College Students' Academic Performance,” J. Psychoeduc. Assess., vol. 37, no. 3, pp. 358-371, 2019. https://doi.org/10.1177/0734282918764202

[15] L. Schudde, "Short-and long-term impacts of engagement experiences with faculty and peers at community colleges," Rev. High. Educ., vol. 42, no. 2, pp. 385-426, 2019. https:// doi.org/10.1353/rhe.2019.0001

[16] F. Darling, Teachin'It! Breakout Moves That Break Down Barriers for Community College Students. Teachers College Press, 2019.

[17] V. Campbell, "ESOL and Content Teachers' Instructional Strategies and the Impact of Engagement on English Language Learners' Academic Success," 2019.

[18] A. Mukminin, A. Habibi, L. D. Prasojo, A. Idi, and A. Hamidah, "Curriculum reform in Indonesia: moving from an exclusive to inclusive curriculum," CEPS J., vol. 9, no. 2, pp. 53-72, 2019. https://doi.org/10.26529/cepsj.543

[19] B. K. Given, Teaching to the Brain's Natural Learning Systems. Alexandria, VA USA: ASCD, 2002.

[20] S. Dehaene, The number sense: How the mind creates mathematics. OUP USA, 2011.

[21] R. E. Slavin, Educational psychology: Theory and practice. 2019.

[22] R. S. Dunn and K. J. Dunn, Teaching young children through their individual learning styles: Practical approaches for grades K-2. Pearson College Division, 1994.

[23] L. S. Vygotsky, Mind in society: The development of higher psychological processes. Harvard university press, 1980.

[24] H. E. Gardner, Multiple intelligences: New horizons in theory and practice. Basic books, 2008.

[25] T. Amstrong, "Multiple intelligent in the classroom," 1994.

[26] T. Amstrong, "Multipple Intelligence," 2010.

[27] B. Cosgrove and J. Richards, "Strategies for Connecting Activities in Physical Education and the Classroom," Strategies, vol. 32, no. 6, pp. 3-8, 2019. https://doi.org/10.1080/08924 $\underline{562.2019 .1657999}$

[28] P. M. Wright, L. L. Zittel, T. Gipson, and C. Williams, "Assessing Relationships Between Physical Development and Other Indicators of School Readiness Among Preschool Students," J. Teach. Phys. Educ., vol. 38, no. 4, pp. 388-392, 2019. https://doi.org/10.11 23/jtpe.2018-0172

[29] S. Harter, "The development of self-representations.," 1998.

[30] B. J. Zimmerman, "From cognitive modeling to self-regulation: A social cognitive career path,” Educ. Psychol., vol. 48, no. 3, pp. 135-147, 2013. https://doi.org/10.1080/004615 20.2013.794676

[31] D. P. Bryant, B. R. Bryant, and D. D. Smith, Teaching students with special needs in inclusive classrooms. Sage Publications, 2019. 
[32] R. M. Gargiulo, D. Metcalf, and D. J. Metcalf, Teaching in today s inclusive classrooms: A universal design for learning approach. Nelson Education, 2017.

[33] I. Hamburg and S. Bucksch, "Inclusive education and digital social innovation," Adv. Soc. Sci. Res. J., vol. 4, no. 5, 2017.

[34] L. Florian and H. Linklater, "Preparing teachers for inclusive education: using inclusive pedagogy to enhance teaching and learning for all," Camb. J. Educ., vol. 40, no. 4, pp. 369-386, 2010. https://doi.org/10.1080/0305764x.2010.526588

[35] E. E. Biggs, "Embedding Peer-Implemented Aided AAC Modeling within a Peer Network Intervention for Students with Complex Communication Needs," 2017.

[36] C. G. Simpson and V. G. Spencer, College Success for Students with Learning Disabilities: Strategies and Tips to Make the Most of Your College Experience. Prufrock Press, 2009.

[37] C. R. Khotari, Research Methodology. New Delhi: NEW AGE INTERNATIONAL (P) LIMITED, 2004.

[38] J. P. Spradley, Participant observation. Waveland Press, 2016.

[39] M. Jamaris and S. Hartati, "The Role of the Undergraduate Students' Self-regulation s and its Influence to their Academic Achievements," Int J Multidiscip. Curr. Res., vol. 5, 2017.

[40] Rasmitadila and A. R. S. Tambunan, "Readiness of General Elementary Schools to Become Inclusive Elementary Schools: A Preliminary Study in Indonesia,” Int. J. Spec. Educ. 2018, vol. 33, no. 2, 2018.

[41] D. D. Preiss, V. Grau, D. Torres Irribarra, and E. Calcagni, "Metacognition, SelfRegulation, and Autonomy Support in the Chilean Mathematics Classroom: An Observational Study," New Dir. Child Adolesc. Dev., vol. 2018, no. 162, pp. 115-136, 2018. https://doi.org/10.1002/cad.20260

[42] M. Arguedas, A. Daradoumis, and F. Xhafa Xhafa, "Analyzing how emotion awareness influences students' motivation, engagement, self-regulation and learning outcome," Educ. Technol. Soc., vol. 19, no. 2, pp. 87-103, 2016.

[43] D. W. Murray and K. Rosanbalm, "Promoting Self-Regulation in Adolescents and Young Adults: A Practice Brief. OPRE Report 2015-82.,” Off. Plan. Res. Eval., 2017.

[44] B. L. Barber, J. S. Eccles, and M. R. Stone, "Whatever happened to the jock, the brain, and the princess? Young adult pathways linked to adolescent activity involvement and social identity,” J. Adolesc. Res., vol. 16, no. 5, pp. 429-455, 2001. https://doi.org/10.1177/074 3558401165002

[45] A. Clarke-Stewart and R. D. Parke, Social development. John Wiley \& Sons, 2014.

[46] N. Schoop-Kasteler and C. M. Müller, "Peer relationships of students with intellectual disabilities in special needs classrooms-a systematic review," J. Res. Spec. Educ. Needs, vol. 20, no. 2, pp. 130-145, 2020. https://doi.org/10.1111/1471-3802.12471

[47] M. Ferreira, C. Aguiar, N. Correia, M. Fialho, and J. S. Pimentel, "Friendships and Social Acceptance of Portuguese Children With Disabilities: The Role of Classroom Quality, Individual Skills, and Dosage," Top. Early Child. Spec. Educ., vol. 39, no. 3, pp. 183-195, 2019. https://doi.org/10.1177/0271121419864419

[48] K. S. Frey and S. B. Nolen, "Taking 'Steps' toward positive social relationships," JL Meece JS Eccles Handb. Res. Sch. Sch. Hum. Dev., p. 478, 2010.

[49] E. W. Carter et al., "Efficacy of peer support interventions in general education classrooms for high school students with autism spectrum disorder," Remedial Spec. Educ., vol. 38, no. 4, pp. 207-221, 2017. https://doi.org/10.1177/0741932516672067

[50] P. C. Candy, Self-Direction for Lifelong Learning. A Comprehensive Guide to Theory and Practice. ERIC, 1991. 
[51] P. C. Candy, "Constructivism and the study of self-direction in adult learning," Stud. Educ. Adults, vol. 21, no. 2, pp. 95-116, 1989.

[52] S. Papadakis, "Evaluating pre-service teachers' acceptance of mobile devices with regards to their age and gender: a case study in Greece.," IJMLO, vol. 12, no. 4, pp. 336-352, 2018. https://doi.org/10.1504/ijmlo.2018.10013372

[53] M. Kalogiannakis, and S. Papadakis, "Combining mobile technologies in environmental education: a Greek case study" International Journal of Mobile Learning and Organisation, 11(2), 108-130, 2017. https://doi.org/10.1504/ijmlo.2017.10005249

[54] S. Papadakis, N. Zaranis, and M. Kalogiannakis, "Parental involvement and attitudes towards young Greek children's mobile usage,” Int. J. Child-Comput. Interact., vol. 22, p. 100144, 2019. https://doi.org/10.1016/j.ijcci.2019.100144

[55] S. Papadakis, and V. Orfanakis, "The combined use of Lego Mindstorms NXT and App Inventor for teaching novice programmers". In International Conference EduRobotics 2016 (pp. 193-204). Springer, Cham. https://doi.org/10.1007/978-3-319-55553-9_15

[56] S. Papadakis, M. Kalogiannakis, V. Orfanakis, and N. Zaranis, "The appropriateness of scratch and app inventor as educational environments for teaching introductory programming in primary and secondary education”. International Journal of Web-Based Learning and Teaching Technologies (IJWLTT), 12(4), 58-77, 2017. https://doi.org/10.40 $\underline{18 / i j w l t t .2017100106}$

[57] S. Papadakis, and M. Kalogiannakis, M. "Evaluating a course for teaching introductory programming with Scratch to pre-service kindergarten teachers.", International Journal of Technology Enhanced Learning, 11(3), 231-246, 2019. https://doi.org/10.1504/ijtel.2019.1 0020447

[58] M. S. Knowles, "Self-directed learning: A guide for learners and teachers.," 1975.

[59] N. K. Ruzaman, "Inquiry-Based Education: Innovation in Participatory Inquiry Paradigm," Int. J. Emerg. Technol. Learn. IJET, vol. 15, no. 10, pp. 4-15, 2020. https://doi.org/10.39 91/ijet.v15i10.11460

[60] R. H. Rafiola, P. Setyosari, C. L. Radjah, and M. Ramli, "The Effect of Learning Motivation, Self-Efficacy, and Blended Learning on Students' Achievement in The Industrial Revolution 4.0," Int. J. Emerg. Technol. Learn. IJET, vol. 15, no. 08, pp. 71-82, 2020. https://doi.org/10.3991/ijet.v15i08.12525

[61] Y. Chen, "Correlation between Self-Efficacy and English Performance," Int. J. Emerg. Technol. Learn. IJET, vol. 15, no. 08, pp. 223-234, 2020. https://doi.org/10.3991/ijet.v15 i08.13697

[62] L. Berk, "Development through the lifespan 6th edition," 2013.

[63] H. W. Marsh and R. Craven, "Academic Self-Concept," in Handbook of Classroom Assessment, Elsevier, 1996, pp. 131-198. https://doi.org/10.1016/b978-012554155-8/50 $\underline{008-9}$

[64] C. Cambra and N. Silvestre, "Students with special educational needs in the inclusive classroom: social integration and self-concept," Eur. J. Spec. Needs Educ., vol. 18, no. 2, pp. 197-208, Jun. 2003, https://doi.org/10.1080/0885625032000078989

[65] R. A. Burns, D. A. Crisp, and R. B. Burns, "Competence and affect dimensions of selfconcept among higher education students: a factorial validation study of an academic subject-specific self-concept,” Eur. J. Psychol. Educ., vol. 33, no. 4, pp. 649-663, 2018. https://doi.org/10.1007/s10212-018-0369-x

[66] M. Ransome, M. E. S. Mohamed, and P. Bridgemohan, "Student Teachers' Beliefs, Feelings and Attitudes toward Mathematics Learning and Teaching at the University of Trinidad and Tobago," World J. Educ., vol. 6, no. 4, p. p38, Aug. 2016, https://doi.org/10. $\underline{5430 / \text { wje.v6n } 4 \text { p38. }}$. 


\section{Authors}

Rasmitadila is a researcher and lecturer of Elementary School Teacher Education Department of Education Faculty in Djuanda University Indonesia. She has worked in some research project in the field of elementary teacher education, instructional system, curriculum and materials development. She is the Editor of the journals: Didaktika Tauhidi, Tadbir Muwahhid, as peer reviewers in The International Journal of Interdisciplinary Educational Studies, International Electronic Journal of Elementary Education.

Reza Rachmadtullah is a lecturer and researcher at the Department of Elementary School Teacher Education, of Education Department Universitas PGRI Adibuana, Surabaya, Indonesia. His research interest is instructional multimedia, instructional strategies and inclusive education.

Anna Riana Suryanti Tambunan is a researcher and lecturer of Education in State University of Medan Indonesia. She has worked in some research project in the field of language.

Achmad Samsudin is a lecturer and researcher at the Department of Physics Education, Faculty of Mathematics and Natural Science Education, Universitas Pendidikan Indonesia, Bandung, Indonesia. His research interest is physics education especially in the mis- conceptions, conceptual change and understanding.

Eri Ester Khairas is a researcher and lecturer of Education in Politeknik Jakarta Indonesia. She has worked in some research project in the field of language teaching, English teaching and Teaching English as a Foreign Language.

Muhammad Nurtanto is a lecturer and researcher at the Department of Mechanical Engineering Education, Faculty of Teaching dan Training Education, Universitas Sultan Ageng Tirtayasa, Banten, Indonesia. My research interest is Media Education, STEM Education, Professional Teaching, Vocational Education, TVET.

Article submitted 2020-04-09. Resubmitted 2020-06-05. Final acceptance 2020-06-05. Final version published as submitted by the authors. 